\title{
The System Construction of Supporting Litigation of Procuratorial Organs in China
}

\author{
Delu Xiong \\ Law School \\ Sichuan University \\ Chengdu, China \\ Law School \\ Sichuan University of Science \& Engineering \\ Zigong, China
}

\begin{abstract}
Procuratorial organs have accumulated rich judicial experience in supporting litigation practice, but there are still some blind spots in theory and practice in China. Based on the judicial practice of public interest litigation, a special department of supporting litigation without the right of judicial supervision should been established, which is responsible for supporting civil litigation activities involving national interests and social interests, so as to constantly improve the system of supporting litigation by procuratorial organs. For cases involving major damage to national interests or social public interests, the procuratorial organs may directly initiate public interest litigation when the litigation subject is absent. Proceeding from the national conditions of social transformation and judicial practice experience, this paper breaks through the fog of system and thinking, and constructs and innovates the system of social participation in litigation with Chinese characteristics to safeguard the public interests of the state, society and citizens.
\end{abstract}

Keywords—procuratorial organ; supporting litigation; public interest litigation; system construction

\section{INTRODUCTION}

In July 2015, the Supreme People's Procuratorate issued the pilot program for the reform of public interest litigation initiated by procuratorial organs, launching a two-year pilot reform of public interest litigation in procuratorial organs in 13 provinces, autonomous regions and municipalities directly under the central government. In June 2017, the Standing Committee of the National People's Congress amended the civil procedure law and the administrative procedure law, formally establishing the system of procuratorial public interest litigation, and making detailed provisions on the jurisdiction, Initiating legal proceedings and trial of public interest litigation cases. The establishment of the procuratorial public interest litigation system has greatly promoted the development of the supporting litigation of procuratorial organs and raised many new problems in practice and theory. This paper will analyze and discuss relevant issues, and put forward suggestions for improvement, so as to promote the institutional functions of procuratorial organs to safeguard the public interests of the state, society and citizens by supporting litigation.

\section{PROBLEMS ON SUPPORTING LITIGATION}

Since 2017, procuratorial organs have conducted extensive judicial practices in supporting litigation in China.[1] In order to safeguard the civil rights and interests of the state, society and citizens, local procuratorial organs at all levels support litigation focus on cases that harm the state and public interests and cause the loss of state-owned assets. They have accumulated rich judicial experience in supporting litigation and promoted institutional practice. At the same time, the supporting litigation of procuratorial organs is still facing many doubts in institution and theory. [2]

The transformation of social life in China has resulted in a large number of behaviors that harm the public interests, such as environmental pollution, infringement of the rights and interests of consumers, consumption of public resources, and group safety accidents. As the representative of public interest, the procuratorial organ intervenes in the civil litigation of this kind of case by supporting litigation, which is a positive response to the demand of social life at present.

"Wise laws, by their very nature, are meant to bring happiness to all, not to a few; otherwise, on one side it is all strength and happiness, and on the other it is only weakness and poverty." [3] It is a kind of institutionalized "wise law" that the supporting litigation of procuratorial organs adjusts the gradually deviant pattern of interest distribution, and balances the sloping litigation order based on safeguarding public interests. From the perspective of judicial practice in supporting litigation of procuratorial organs, this paper discusses some important issues in supporting litigation, so as to promote the institutionalization of "wise law".

\section{TheOretical VALUE OF SUPPORTING Litigation OF PROCURATORIAL ORGANS}

"In the modern society under the rule of law, procuratorial organs are known as the representatives of public interests, that they take public interests as their 
foundation, so safeguarding public interests should become an important principle of activities of procuratorial organs." [4]

With the change of social life, mass problem has become a serious social problem in China. The disposition of the civil rights and interests of the parties concerned in such cases often seriously affects the public interest, and according to the principle of social intervention, the state and society have the duty to intervene in accordance with the law. The supporting litigation of procuratorial organs can effectively deal with the illegal behavior with group social harm that the private interest litigation can not restrain, and protect the interests of the state, society and vulnerable groups.

At present, the purpose of civil litigation in China is diversified, including solving civil disputes, realizing rights protection and maintaining the order of private law. [5]China is promoting the rule of law construction, in which the private law order is the basic link. The civil action of individual case not only has the value of individual case, but also has the value of public, which has the function of constructing and maintaining the order of private law. When the operation of civil litigation right may disrupt the order of private law, it needs to be adjusted and corrected. Procuratorial organs, as legal supervision organs, have the power and obligation to maintain the unity of the order of private law. In fact, order is a social good. It is reasonable and necessary for the procuratorial organs to intervene in the civil litigation appropriately in the way of supporting litigation from the purpose of maintaining the public welfare.

\section{PRACTICAL REASON OF SUPPORTING LitigATION OF PROCURATORIAL ORGANS}

Although faced with many institutional gaps, judicial practice shows that the supporting litigation of procuratorial organs conforms to the changes of the times, meets the needs of social life, and accumulates important institutional practice experience, which is conducive to strengthening the legal supervision function of procuratorial organs and maintaining fairness and justice.

First, supporting litigation is an inevitable choice for the institutional innovation of procuratorial organs. An important content of the judicial reform of procuratorial organs is the innovation of the civil administrative procuratorial system. In response to the changing social life, the procuratorial organs should actively explore the institutional conditions for realizing the function of civil litigation under the new situation and participate in civil litigation activities effectively. The practice of supporting litigation reflects the innovation value of the procuratorial system.

Second, supporting litigation of procuratorial organs can safeguard the national and social public interests. Since 2010, 21 households have illegally built over 70,000 square meters of land on both sides of roads in Mangya, Qinghai province in China, and the local bureau of land resources and environmental protection and forestry failed to effectively perform its duties of administrative supervision over these illegal acts. In 2018, local procuratorial organ filed a public interest lawsuit against the illegal act as a public interest litigation subject, and the court ruled in favor of all the prosecution's claims. [6] It is a kind of "transformation tumor" to violate national and social public welfare in the process of China's social transformation, and a typical case is the recessive or explicit appropriation of state assets. Procuratorial organs, on behalf of the state and the public good, shall support and supervise relevant departments in filed a lawsuit against acts that cause the loss of state-owned assets, and relieve the damaged public interests through judicial procedures.

Third, supporting litigation of procuratorial organs is conducive to relieve the interests of the disadvantaged and maintain social stability. Environmental pollution, product quality, food hygiene and other problems are the focus of current social life. They involve a wide range of areas and tend to lead to mass incidents, which are not conducive to social stability. The infringing party in such cases is often in a strong position, while the injured party is usually weak and it is difficult to sue on its own strength. And it's hard to get evidence in such cases. Meanwhile, there are higher litigation costs and it is difficult to form group litigation. So it is necessary for procuratorial organs to actively intervene in such cases to help implement legal relief and realize a harmonious social order.

\section{SYSTEM CONSTRUCTION OF SUPPORTING LITIGATION}

To construct the institutionalized supporting litigation, the procuratorial organs need to give play to the theoretical imagination on the basis of judicial practice, design and refine the legal rules in line with the transformation of social life.

\section{A. Subject of Supporting Litigation}

The civil administrative procuratorial department of the procuratorial organ is the supervising organ of civil and administrative litigation, and it also performs the function of supporting litigation in the current system practice. The role of civil administrative procuratorial departments in supporting litigation is that of participants in proceedings, at the same time that of supervisor in proceedings. Obviously there is "a stigma of being both athlete and referee". Therefore, the procuratorial organs should set up a special body to support litigation, which would no longer have the power to supervise trials. When the judgment of the court is inconsistent with that of the department of supporting litigation of procuratorial organs, the latter may suggest that the judicial supervision department review the problems existing in the court's judicial activities and decide whether to protest according to law. [7]

\section{B. Scope of Supporting Litigation}

Different from ordinary civil subjects, the activity of supporting litigation based on procuratorial power. Therefore, the scope of support litigation should focus on the balance between the protection of social interests and the national interest, rather than blind intervention without identification. 
In essence, the supporting litigation of procuratorial organs embodies a kind of social substantive justice.

Based on practical experience and legal logic, the cases of supporting litigation of procuratorial organs have the following characteristics: First, national interests, collective interests and social and public interests are violated; Second, there are parties who have the right of action; Third, the parties are often vulnerable groups whose legitimate rights and interests are infringed but whose litigation is difficult and inconvenient. Typical cases include loss of state-owned assets, environmental pollution, damage to public facilities, destruction of natural resources, protection of consumers' rights and interests, and violation of public order and good customs.

\section{Investigation and Evidence Collection of Supporting Litigation}

Investigation and evidence collection is the premise and basis for procuratorial organs to carry out activities in supporting litigation. The procuratorial organs need to collect enough evidence to prove that the social welfare or the rights and interests of vulnerable groups in the society have been infringed, and obtain the consent of the victims before they can maintain justice by supporting litigation. Therefore, the procuratorial organs should be given the right to investigate and collect evidence in supporting litigation.

Of course, the procuratorial organs' right to investigate and collect evidence should not be compulsory. If the unit or individual concerned is not subject to investigation, the procuratorial organ cannot take coercive measures. Although mandatory investigation and collection of evidence by procuratorial organs can greatly improve the efficiency of litigation and reduce the cost of litigation, it may lead to the negative impact of the interference of public power in private rights, resulting in substantial inequality between the parties. After all, it is the right of a party to a civil action, not the power of a legal supervision agency, to investigate and collect evidence when supporting litigation.

\section{Patterns of Supporting Litigation}

Procuratorial organs have formed different patterns of supporting litigation in judicial practice: firstly, prior supervision: Through submitting "opinion of supporting litigation" to the court, to support the parties to participate in the proceedings, but not to intervene in the subsequent litigation activities. Secondly, submitting "opinion of supporting litigation" to the court and participating in court to support litigation, so as to supervise the trial activities. Thirdly, the procuratorial organs actively investigate and collect evidence, send officers to attend court hearings, exercise the litigation rights of the parties, and issue opinions supporting litigation after the court debate. The judicial practice of supporting prosecution by procuratorial organs has enriched the system rationality, and there is an important resource to construct the system of supporting litigation, accompanying with the judicial practice of supporting litigation of procuratorial organs, which has enriched the system rationality.
Legal assistance: In many cases of infringement on vulnerable groups, the relief of victims' rights needs social assistance, which is an important manifestation of social justice. The stage of social transformation inevitably produces vulnerable groups, who lack necessary knowledge, resources and even courage. When confronted with the infringement of too powerful forces, they dare not sue, do not know to sue, or are unable to sue. In this case, by assisting the parties to take litigation, the procuratorial organs can help them relieve their rights and restore social fairness and justice.

To supervise relevant units to exercise the right to sue: This approach applies to cases in which the national interest and social good are infringed. The procuratorial organ may, in the form of "opinion of urging the litigation" or "opinion of the procuratorial proposal", request the relevant units to take a lawsuit to relieve the state and the public interest. If the unit concerned fails to perform its duties, the procuratorial organ may investigate its responsibility through legal supervision.

To take directly public interest litigation: For cases involving the loss of state-owned assets, unfair competition, environmental pollution and other major damage to national interests or public welfare, procuratorial organs may directly and independently file lawsuits as representatives of the state and public welfare to investigate the civil liability of the infringer, if the unit concerned is reluctant to take a lawsuit When the procuratorial organ supervises it to exercise the right to sue. In cases involving major social public interests, when the litigation subjects are absent, including the litigation subjects that should have become the plaintiff die out and are unable to file a lawsuit, the procuratorial organ may formulate to participate in the lawsuit as the plaintiff as the public interest representative, so as to effectively safeguard the social public interest. [8]

\section{CONCLUSION}

Against the background of social transformation, the theory of social intervention does not seem to adapt to the context of supporting litigation in the new era. Supporting litigation of procuratorial organs is a realistic need to safeguard the national and social public welfare, an inevitable requirement for the reform and development of civil administrative procuratorial work, and an important institutional construction for procuratorial organs to maintain fairness and justice. At present, based on the judicial practice of public interest litigation, we should break through the fog of system and thinking, constantly explore and improve the mechanism of supporting litigation of procuratorial organs, and scientifically construct the system of social participation in litigation with Chinese characteristics to safeguard the public interests of the state, society and citizens. [9]

\section{REFERENCES}

[1] Jun Zhang. Report of the Supreme People's Procuratorate on the procuratorial work of public interest litigation: At the 14th Session of the Standing Committee of the 13th National People's Congress on 
oct 23, 2019, the web page of the Supreme People's Procuratorate, https://www.spp.gov.cn, browsing on December 7, 2019.

[2] Housheng Duan.On Supporting Litigation of Procuratorial Organs. Politics and Law, 2004(6); Guohua Jiang, Bin Zhang. Seven Basic Poblems of Civil Environmental Public Interest Litigation in China: From "the Case of the Environmental Protection Federation of a City Sues a Chemical Company Environmental Pollution", Review of Political Science and Law, 2017(2).

[3] Beccaria. On Crime and Punishment. Trans. Huang Feng. Peking University press. 2008: 6

[4] Zhen Zhen. Theory of Legal Supervision, Law press, 2007:80

[5] Zhengzhou Lv. The Contradiction Analysis of the Pluralism of the Purpose of Civil Litigation, Law and society, 2008(29)

[6] Collaborative Innovation Center of Judicial Civilization. Qinghai province has released four typical cases of public interest litigation in China, browsing on December 7, 2019.

[7] Guohua Jiang, Bin Zhang. Seven Basic Poblems of Civil Environmental Public Interest Litigation in China: From " the Case of the Environmental Protection Federation of a City Sues a Chemical Company Environmental Pollution", Review of Political Science and Law, 2017(2).

[8] Bixin Jiang. The Practice Development and System Consummation of Environmental Public Interest Litigation in China, Application of Law, 2019(1).

[9] Gang Chen. Re-recognization on Legal Theory and Practical Significance about the Principle of Supporting Litigation, Legal Research, 2015(5). 